\title{
Transformation of Poaceae and gene expression in transgenic plants
}

\author{
J Fütterer, I Potrykus \\ Institute for Plant Sciences, Federal Institute of Technology, ETH Zürich, Universitätstr 2, CH 8092 Zürich, Switzerland
}

(Received 22 May 1995; accepted 4 July 1995)

\begin{abstract}
Summary - All major Poaceae have been transformed in recent years. This review gives a brief overview of the methods used for transformation and for achieving controlled gene expression in transgenic plants and discusses the problems that are still encountered when transformation technology is applied for practical purposes.
\end{abstract}

transformation / monocot / gene expression / transgenic plant

Summary - Transformation des Poaceae et expression de gènes dans les plantes transgéniques. Les espèces les plus importantes de la famille des Poaceae ont été transformées au cours de ces dernières années. Cet article résume les différentes méthodes utilisées pour la transformation et le contrôle de l'expression des gènes dans les plantes transgéniques. Les problèmes liés à l'utilisation des techniques de transformation en recherche appliquée sont également discutés dans cet article.

transformation / monocotylédones / expression génique / plante transgénique

\section{INTRODUCTION}

The establishment of transformation protocols for monocots in general and particularly for cereals and grasses has lagged behind transformation of many dicots. However, after a very long period of development, many Poaceae, including all the economically important ones, have finally been transformed during the last 6 years (table I). However, the transformation of most of the species is still inefficient and is reported only for a few isolated cases. The notable exceptions are rice (japonica varieties) and maize where relatively high transformation efficiencies can be reached routinely, and the commercialization of the first transgenic maize is to be expected soon.
In general, transformation efficiencies are very genotype dependent and, for the establishment of the transformation methods, lines or cultivars that show particularly good tissue culture responses have been used. These lines, however, are usually not the economically important ones and transfer of transformation technology to lines of agronomical interest, has, in most cases, yet to be accomplished.

This brief review will provide a subjective overview of the latest achievements in the field of the transformation of Poaceae and the conclusions that can be drawn from this work. The references given are meant to provide illustrative examples rather than a complete list of the published work. The discussion will be restricted to 
points relevant for stable transformation and to examples where proof for stable integration of a transgene has been provided by molecular genome analysis.

\section{PLANT MATERIAL}

The choice of a suitable starting material was crucial to the development of the transformation technology. Tissues or cells with the competence to take up, integrate and express DNA, and to develop into a mature, fertile plant, had to be found.

Following the early work in dicot transformation, also for cereals, the transformation of protoplasts has been successful (table I). Protoplasts have been obtained from embryogenic cell suspensions, which, with different methods of DNA delivery (see below), were later used directly for transformation. The use of embryogenic cell suspensions offers a variety of advantages over material that must be isolated for each experiment directly from plants, but the initial establishment of such a culture is time-consuming and requires experience. Once such a culture has been established, material for transformation experiments can be readily amplified and largescale experiments can be performed relatively easily. The uniformity of the starting material allows the introduction of DNA into a large number of cells simultaneously and simple selection schemes can be employed because transgenic cells do not have to be selected from the nontransgenic tissue in which they are embedded. The major disadvantage of this approach is the long time that the plant material should be kept under very artificial tissue culture conditions. During this time, parts of the plant genome are not under a functional selection and mutations or epigenetic changes can accumulate, resulting in phenotypically aberrant plants (albinos, sterile plants, etc). These problems can be partially overcome by either continuous establishment of new cultures, which are then only used during a short period of time (about 3 months), or by cryopreservation of cultures in a 'young' state early after establishment (Lynch et al, 1994; Wang et al, 1994). However, the period required for establishment of a culture may be long enough to cause mutational changes. A further disadvantage of such cell cultures is the apparently greater genotype dependence of the method.

To avoid these long tissue culture phases, regenerable tissue has been isolated directly from plants. The most widely used explants are immature, zygotic embryos (table I). DNA delivered either directly to the scutellum or to calli derived from the scutellum is expressed and integrated at least in some cells. Selectable, antibiotic- or herbicide-resistant calli and (under appropriate conditions) plants can develop from such cells. Plant regeneration from scutellumderived calli still shows a strong dependence on the genotype of the donor plant, although these effects may be less pronounced than with cell suspensions. It has been reported for rice that regeneration (and transformation) is equally effective with a wide range of different genotypes including indica rice varieties which are otherwise very difficult to transform (Cooley et al, 1995). In our hands, however, japonica rice lines still respond about 100 times more efficiently than the recalcitrant indica lines; similar genotype dependencies were observed in work with wheat with some cultivars showing almost no suitable tissue culture response at all. It remains to be seen whether these adverse genotype effects can be overcome by variation of the tissue culture conditions or whether they really provide an intrinsic block.

A high percentage of the plants derived from scutellum are phenotypically normal although problems with fertility may still be encountered. The disadvantages of the method for routine use are the requirement for a continuous supply with appropriate seed material and the necessity to isolate and handle a large number of immature embryos, particularly in those cases where the transformation efficiencies are low (eg, 1 plant per 500 treated embryos; Weeks et al, 1993). Selection for transgenic tissue may also be more difficult.

Other plant materials like microspores (Jähne et al, 1994), inflorescence (Barcelo et al, 1994) and apical meristems (Lowe et al, 1995) have occasionally been used with success. The future will show how generally applicable these alternatives are.

\section{DNA DELIVERY}

Several methods have been used to deliver DNA to isolated plant cells or plant tissues (table I). For protoplasts, treatment with polyethylene glycol (PEG) or electroporation leads to uptake of DNA into a large number of cells without damaging these cells too much to interfere with their viability. Cells that are still surrounded by a cell-wall, 
ie intact suspension cells or cells in tissue, require a treatment that can overcome this barrier.

The present method of choice is the delivery of DNA bound to microcarriers that are accelerated by different methods, so that they can penetrate through the cell wall and enter cells by mechanical force. Several different methods to link DNA to the microcarriers and to accelerate these particles have been successfully used and have also been commercialized. In general, gold particles as microcarriers have less adverse effects on cell viability than tungsten particles, and particle acceleration by pulses with inert gases is preferable over the previously used gun powder explosions (reviewed by Christou, 1993). The most widely used particle gun is the PDS-1000/He device (Kikkert, 1993) which is available from Du Pont. We have used a simpler particle inflow gun, which was home-made according to Finer et al (1992), with success.

Surprisingly, DNA can also be introduced into intact cells by electroporation (table I; Klöti et al, 1993; Songstad et al, 1993). This method could have the advantage that the cells that take up DNA are less stressed than by particle bombardment (Hunold et al, 1994). However, so far, electroporation conditions have not been optimized for much of the plant material in question and too few examples have been reported for a comparison of the 2 methods.

Other methods to introduce DNA into cells or tissue involve microinjection (Simmonds et al, 1992; Lusardi et al, 1994), DNA application to growing pollen tubes (Luo and $\mathrm{Wu}, 1988$ ), and shaking cells with small silicon carbide crystals (whiskers) in a DNA solution (Kaeppler et al, 1992; Frame et al, 1994). The last method is experimentally very simple and does not require any expensive equipment; the general applicability of the other methods (assessed by Potrykus, 1990) remains to be proved.

One reason for the delay between transformation of monocots and dicots was the apparent unresponsiveness of monocots to treatment with Agrobacterium. Agrobacterium-mediated infection of cereals with DNA viruses provided the first indications that agrobacteria can in fact transfer DNA to cereals (Grimsley et al, 1987) and recently transgenic rice plants with stably integrated, Agrobacterium-transferred DNA have been described (Chan et al, 1993; Hiei et al, 1994). Attempts to repeat this success with other cereals are underway in many laboratories but have to our knowledge only resulted in transient expression events.
In monocots, the applicability of Agrobacterium-mediated gene transfer would not overcome the requirement for regenerable starting material, but may provide a more efficient and less destructive method of DNA delivery to this material. Furthermore, integration patterns after Agrobacterium-mediated transformation are usually simpler than with all methods of direct DNA delivery where rearrangements and truncations of the transfected DNA are very frequent and where integration of multiple copies at one or more loci is the rule. It is generally believed that the expression patterns of single copy transgenes are more stable and predictable than those of multiple copies (Spencer et al, 1992; Cooley et al, 1995).

For applications, genes besides the selectable marker must be introduced. These genes can be located on the same DNA fragment or can be supplied on separate fragments. Cotransformation rates between 20\% (Peng et al, 1990; Rathore et al, 1993) and 100\% (Goto et al, 1993; Barcelo et al, 1994; Wan and Lemaux, 1994) have been reported for genes provided as unlinked DNA fragments. With linked genes, rates of $100 \%$ are normal (Cooley et al, 1995).

\section{SELECTION OF TRANSGENIC PLANT TISSUE}

Transgenic cells or tissues are regenerated in the presence of selective agents. Four genes that encode proteins detoxifying antibiotics or herbicides have mainly been used for cereals and grasses (table I):

1) The nptll gene of the Escherichia coli transposon Tn5 confers resistance to kanamycin and related compounds like geneticin (Bevan et al, 1983). Kanamycin was used initially for some cereals. In cases where endogenous resistance against kanamycin and/or interference with regeneration were encountered, geneticin proved to be a valuable alternative.

2) The hptl gene isolated from $E$ coli confers resistance to hygromycin (Gritz and Davies, 1983) and was mainly used for rice transformation and for some grasses. Selection conditions can be used that are very tight and almost exclusively allow growth of transgenic material.

3) Genes coding for methotrexate-resistant dihydrofolate reductases (DHFR) have been isolated from $E$ coli (Pattishall et al, 1977) and a mouse DHFR gene was modified to encode a resistant protein (Eichholtz et al, 1987). The gene allowed effective selection of transgenic wheat and rice. 


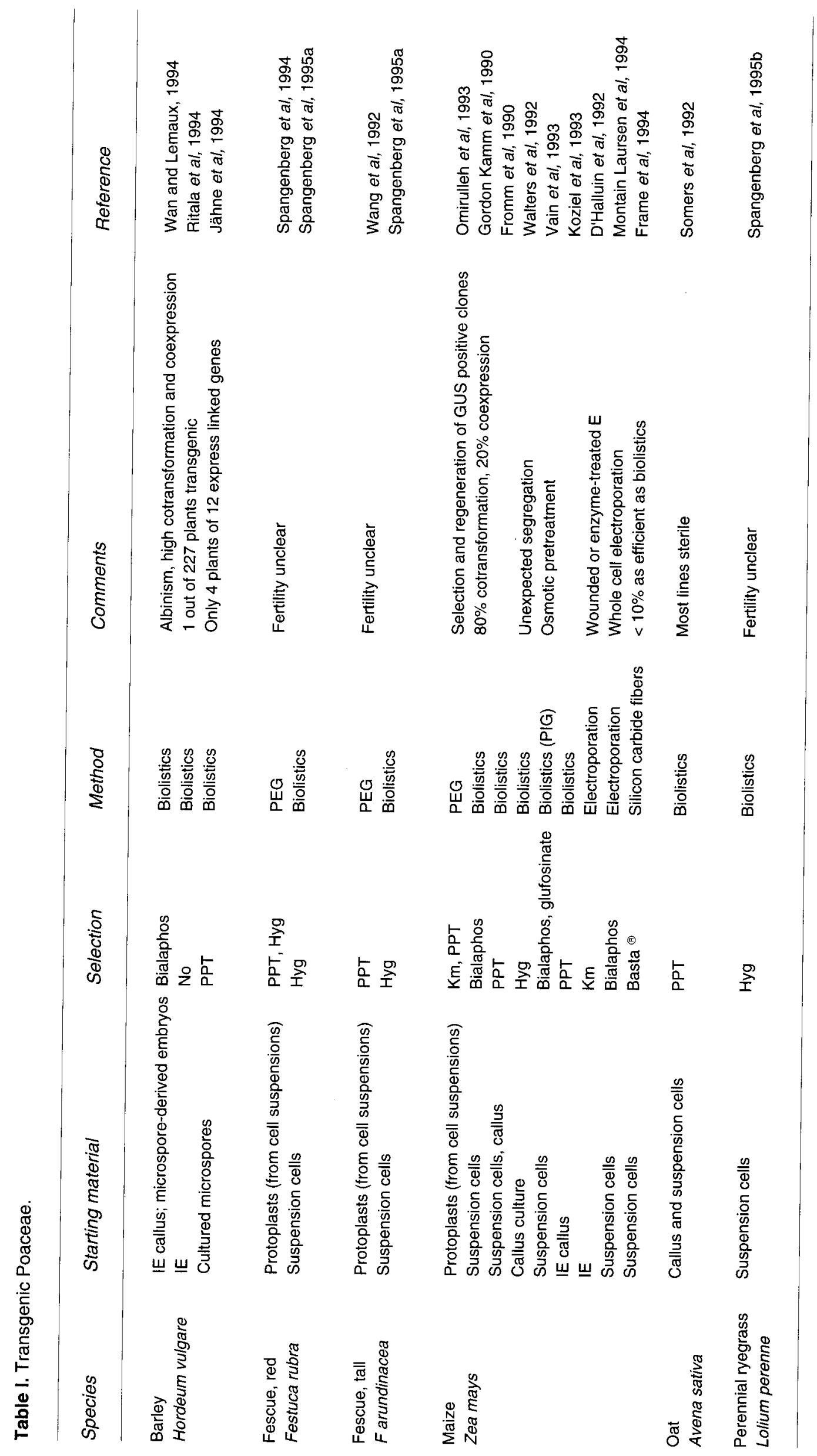




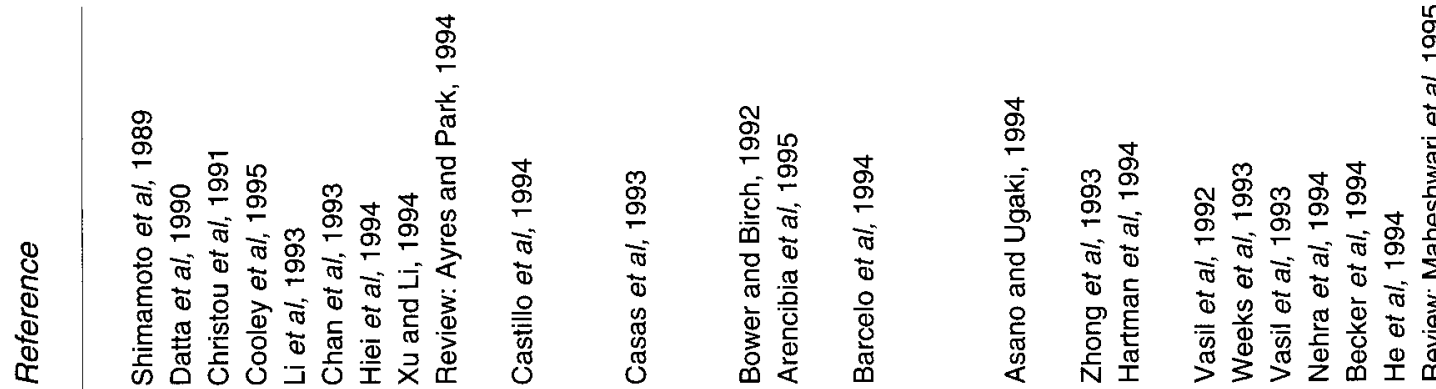

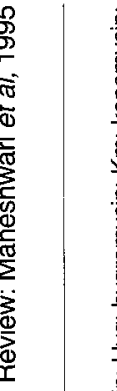

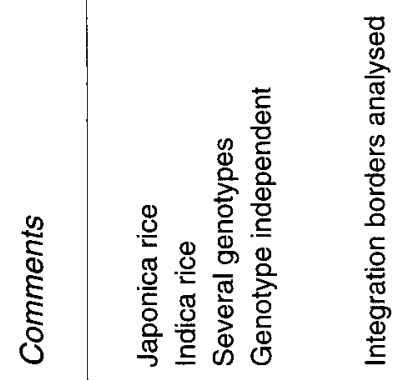
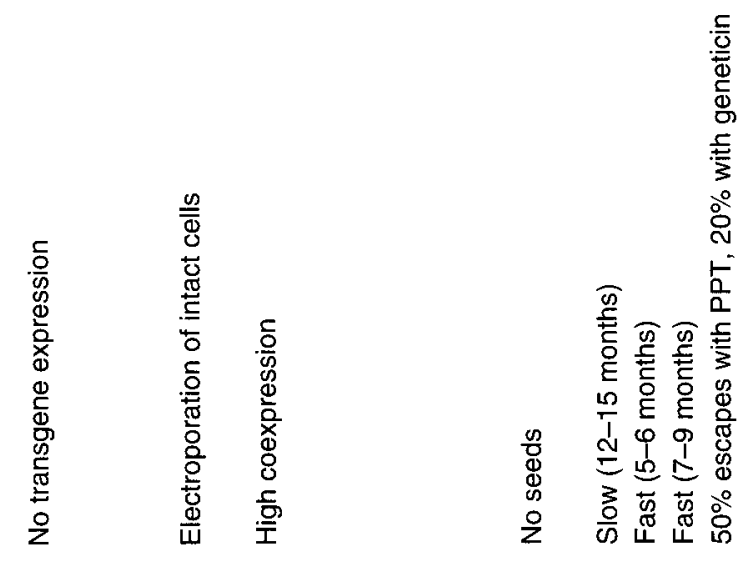

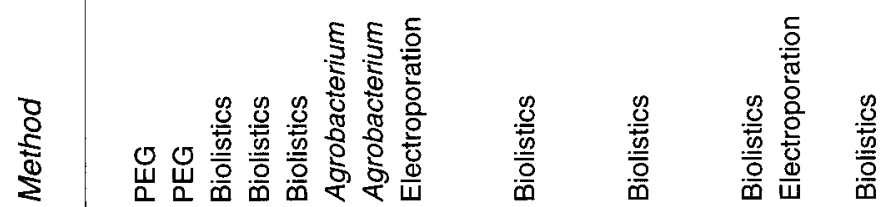
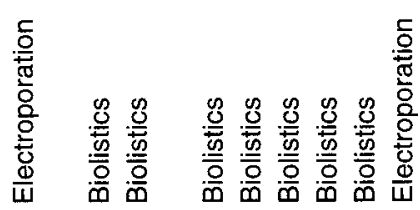

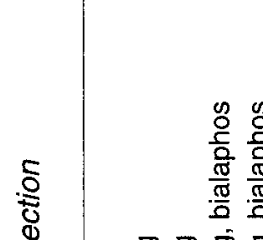

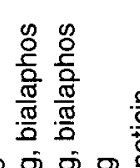

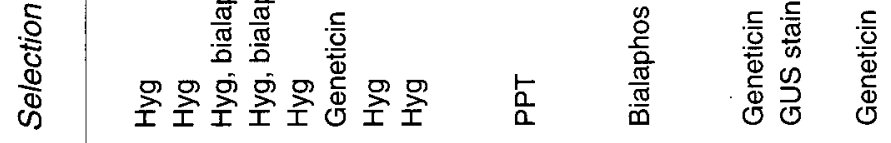

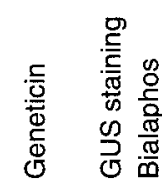

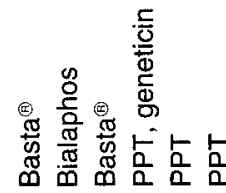

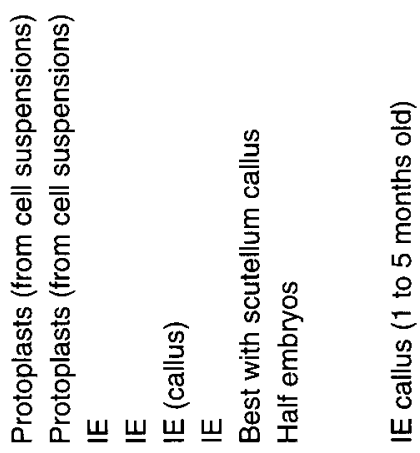

8
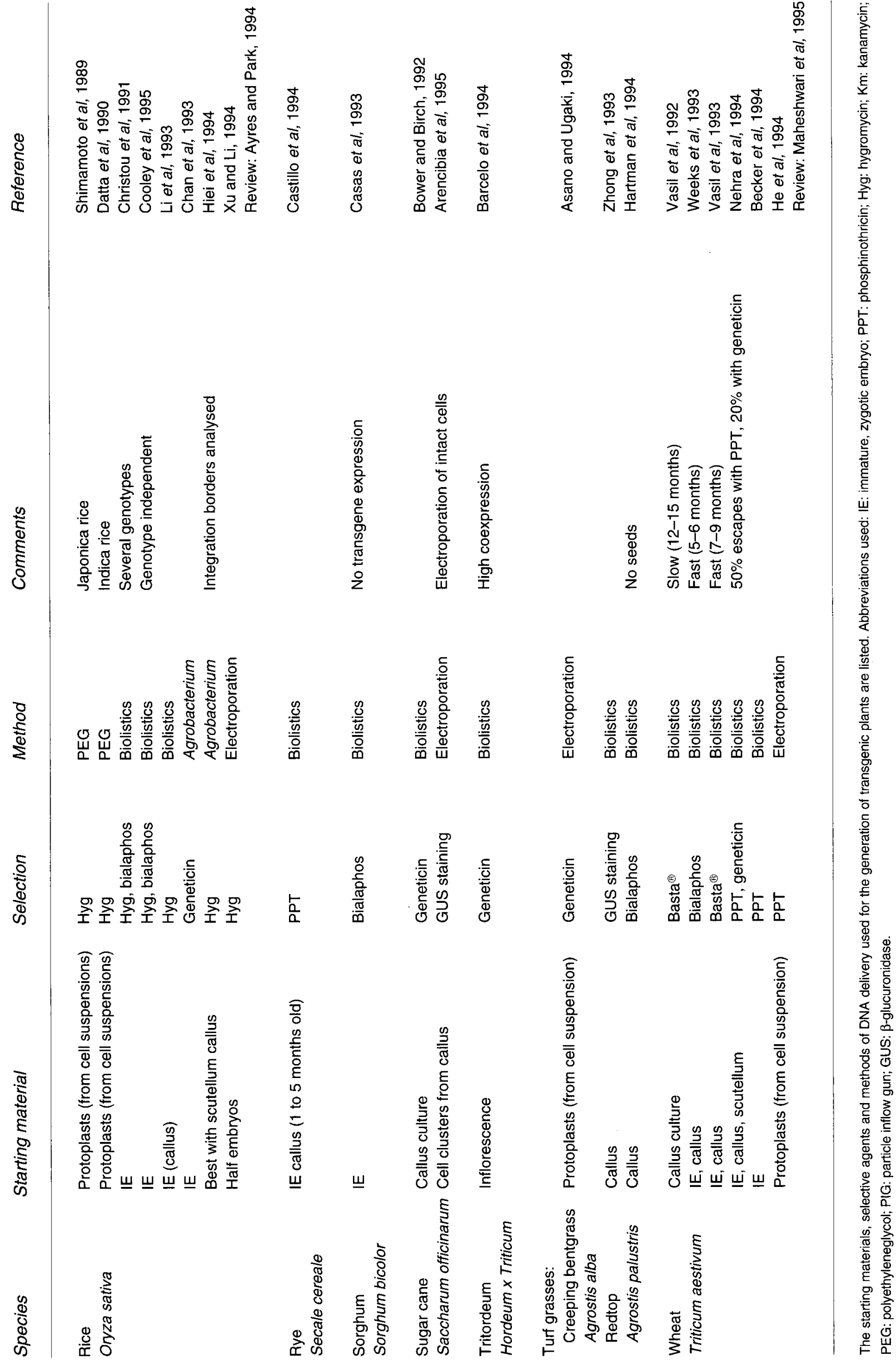
Selection for methotrexate resistance has a potential advantage over the other selection schemes mentioned in which a selective agent has to be detoxified by a transgene-encoded enzyme. Low enzyme activity or low accessibility of the selective agent to the enzyme may result in incomplete detoxification. The balance between transgene expression and concentration of the selective agent could be more critical than in the case of methotrexate where plant cells containing low levels of the resistant DHFR may also survive in high concentrations of methotrexate.

4) The bar gene of Streptomyces hygroscopicus (Murakami et al, 1986) and the pat gene from $S$ viridiochromogenes (Wohlleben et al, 1988 ) both confer resistance to the herbicide compound phosphinothricin (PPT) and its derivatives Basta ${ }^{\circledR}$ and bialaphos. The gene was useful for selection in a wide variety of Poaceae. Selection can be accomplished either by addition of the compound to the growth medium or by spraying the plantlets. The precise selection scheme must be optimized for each species and each starting material. Concentrations of PPT that would allow a $100 \%$ effective selection can interfere with the regeneration capacity of the tissue (eg, in wheat transformation; Nehra et al, 1994). Suboptimal amounts therefore are being used which also allow growth of some untransformed material. In such cases, it is important to continue selection throughout plant regeneration. Nevertheless, the bar gene presently seems to be the selective gene of choice for all Poaceae, except rice where selection with hygromycin is very well established.

In a few cases, transgenic material has been selected by a sublethal GUS staining (Omirulleh et al, 1993; Arencibia et al, 1995). After a brief exposure to the reagents required for staining, some cells are still viable and can further proliferate and regenerate. This method is necessarily inefficient and only recommendable if no other selection system is available or if the presence of a selectable marker in a transgenic plant is undesirable. The detection of the activity of genes regulating anthocyanin synthesis would not require a staining process but the expression of these anthocyanin genes may interfere with viability of the cells (unpublished observations; also mentioned in McElroy and Bretell, 1994). The recently described green fluorescent protein from Aequorea victoria may provide an alternative visible selectable marker in the future (Chalfie et al, 1994).

\section{GENE EXPRESSION}

The expression of transgenes is affected by control signals within the transferred DNA but also by sequences surrounding it. These latter position effects make any assessment of the function of transferred expression signals in transgenic Poaceae difficult. In most cases, only very few plants have been analysed with a given construct. Since the variations between independent transgenic plants and even between different plants derived from the same initial transformation event can be considerable, the low numbers of such plants that have been analysed prevent a meaningful statistical evaluation. Most of the data referring to the comparison of expression signals are therefore derived from transient expression systems (Last et al, 1991; McElroy et al, 1991; Chibbar et al, 1993).

For the expression of the selectable marker gene, promoters are required that express at a high level in most of the plant cells. The most commonly used constitutive promoters are the cauliflower mosaic virus (CaMV) ${ }^{35} \mathrm{~S}$ promoter, the maize ubiquitin 1 promoter and the rice actin 1 promoter (reviewed in McElroy and Brettell, 1994).

The CaMV ${ }^{35} \mathrm{~S}$ promoter is the most widely used promoter in dicot transformation and was naturally also tested in the early attempts of monocot transformation. It was found to be active in cereals and grasses and was used in its wildtype form for the expression of selectable and screenable marker genes. However, widely different activity levels have been reported for different expression systems with a general tendency towards low expression levels. The promoter was therefore modified by duplication of its own enhancer (Omirulleh et al, 1993), by insertion of other transcriptional enhancers (Olive et al, 1990; Last et al, 1991) or by combination with intron sequences (Tanaka et al, 1990; see also below). In mature plants, the promoter may exhibit some tissue specificity for the vascular tissue but it is also reported to be active in more or less all cells (Battraw and Hall, 1990; Terada et al, 1990). In our hands, an intron-enhanced CaMV ${ }^{35} \mathrm{~S}$ promoter is mainly active in the mesophyll cells of old rice leaves and weak in the vascular tissue and the epidermis, but shows considerable variation during plant development.

The maize ubiquitin 1 promoter together with the first intron of the gene (Christensen et al, 1992) seems to be the strongest monocot expression signal at least in protoplasts. It is now 
widely used for cereal transformation (Toki et al, 1992; Weeks et al, 1993). It is regarded as a constitutive promoter; however, in transgenic plants, transgenes were shown to be active mainly in young tissue and transgene activity was inducible by stress (Cornejo et al, 1993).

Gene expression cassettes have also been constructed with the rice actin 1 promoter together with the first intron of the gene (McElroy et al, 1991). Very high activities could again be obtained in single cell systems and constitutive expression was observed in transgenic plants (Zhang et al, 1991).

A very strong constitutive promoter has been constructed by a combination of several multiplied enhancer elements (pEmu: Last et al, 1991).

For purposes of tissue-specific or inducible expression, a number of specific promoters mainly from maize and rice are available, which are functional in transgenic plants (Kyozuka et al, 1991, 1993; Schäffner and Sheen, 1991; Gotor et al, 1993; Koziel et al, 1993; Xu et al, 1993; Zheng et al, 1993; see also McElroy and Brettell, 1994; Terada et al, 1995). Tissue-specific dicot promoters have also been used in monocots but expression levels are often quite low and expression specificities may be different (Luan and Bogorad, 1992; Kyozuka et al, 1993). It remains to be seen whether monocot promoters in heterologous monocot plants will always show a better predictable activity than dicot promoters.

It has become practice to include introns in gene expression cassettes for transformation of Poaceae. This is based on experiments in protoplasts that showed that the presence of introns can enhance gene expression up to 100-fold (Callis et al, 1987; McElroy et al, 1990; Last et al, 1991; Maas et al, 1991; Chibbar et al, 1993). It should be noted that these data are frequently derived from comparisons of constructs that varied by more than just the presence or absence of an intron and that very different stimulation factors have been observed in different expression systems (Oard et al, 1989; Vasil et al, 1989; Last et al, 1991; Luehrsen and Walbot, 1991; Rathus et al, 1993). The effect of an intron can drastically depend on the promoter with which it is combined (Last et al, 1991) and in some gene expression systems, introns that lead to an enhancement of expression in cereals even reduced gene expression (eg, sugarcane; Rathus et al, 1993). The molecular basis of expression enhancement by introns in unclear. Post-transcriptional effects on the processing of primary transcripts (including splicing, polyadenylation and transport to the cytoplasm) are probable but the presence of position-dependent enhancer elements cannot be excluded for some cases. The most effective region for intron insertion into expression constructs seems to be the $5^{\prime}$ of the coding region either upstream or in the open reading frame. It is therefore crucial for efficient translation that the intron is properly removed by splicing. Generally, monocot and dicot plant introns seem to be spliced efficiently in monocots while monocot introns are not well recognized in dicots (Goodall and Filipowicz, 1989; Peterhans et al, 1990; McElroy et al, 1991). The relatively poor knowledge about splicing in plants and particularly in monocots make it advisable to test intron-containing constructs before routine use. Another element usually present in expression cassettes is the polyadenylation signal. In dicots, very large effects on the expression efficiencies of different signals have been reported (Ingelbrecht et al, 1989). In monocots only a few have been compared and so far no significant differences have been observed (McElroy et al, 1995).

Sequences in the coding region of the transgene may have a negative effect on expression efficiency. In genes derived from bacteria, the codon usage can often be very different from that of the plant (Murray et al, 1989; Campbell and Gowri, 1990) and clusters of rare codons may slow down translation. Furthermore, prokaryotic genes are not adapted to the RNA-processing machinery of the plant nucleus and may accidentally contain features that cause aberrant processing or degradation of the RNA. Modification of the coding sequence by excessive mutagenesis to remove such potentially deleterious features has been shown to cause strong increases of expression of the respective genes (Perlak et al, 1991; Fujimoto et al, 1993; Koziel et al, 1993).

\section{TRANSGENE INHERITANCE AND STABILITY OF GENE EXPRESSION}

Data on the fate of a stably integrated transgene in cereals over several generations have only been published for very few cases. While inheritance of a gene usually follows the Mendelian rules (Christou et al, 1991; Castillo et al, 1992; Toki et al, 1992; Vasil et al, 1992), transgene expression in the offspring of a transgenic plant can be quite unpreditable (Meijer et al, 1991; Spencer et al, 1992; Walters et al, 1992; Murry et 
al, 1993; Register et al, 1994). The analysis is frequently complicated by the presence of more than 1 transgene copy. Genes may be physically present but gene activity may nevertheless be lost (Gordon-Kamm et al, 1990; Jähne et al, 1994). Loss of gene activity can occur in the primary transformant or in the offspring, and different linked genes can be affected differently. It has been found in several cases, that an unselected gene is not or only poorly expressed, although the linked selectable gene is strongly expressed (Spencer et al, 1992; Nehra et al, 1994; Register et al, 1994). Expression characteristics of 2 different, non-selectable genes can also be different (Cooley et al, 1995). Transgenic plants can also become chimaeric for the expression of a transgene (Gordon-Kamm et al, 1990).

At present, no general conclusions about the frequency of loss of gene activity and about the mechanisms causing such losses can be made. In dicots, silencing effects are often (but not always) related to the presence of multiple copies of a gene or a promoter but in these better examined cases the actual mechanism and the frequency of occurrence are unknown. If duplication of sequences also causes silencing in monocots, the use of homologous promoters or introns could cause problems for long-term gene stability, which could be avoided by the use of virusderived signals. A variety of monocot DNA viruses (Geminiviruses and Pararetroviruses) could provide such signals but only very few have so far been tested in transgenic plants (Medberry and Olszewski, 1993; Yin and Beachy, 1995).

\section{ACKNOWLEDGMENTS}

We wish to thank all our colleagues at the ETH for sharing their experiences of the transformation of rice, wheat and grasses and $C$ Fischer for translation of parts of the manuscript into French. JF Gratefully acknowledges support by the Swiss National Foundation.

\section{REFERENCES}

Arencibia A, Molina PR, de la Riva G, Selman-Housein $G$ (1995) Production of transgenic sugarcane (Saccharum officinarum $L$ ) plants by intact cell electroporation. Plant Cell Rep 14, 305-309

Asano Y, Ugaki M (1994) Transgenic plants of Agrostis alba obtained by electroporation-mediated direct gene transfer into protoplasts. Plant Cell Rep 13, 243-246
Ayres NM, Park WD (1994) Genetic transformation of rice. Crit Rev Plant Sci 13, 219-239

Barcelo P, Hagel C, Becker D, Martin A, Lörz H (1994) Transgenic cereal (tritordeum) plants obtained at high efficiency of microprojectile bombardment of influorescence tissue. Plant J 5, 583-592

Battraw MJ, Hall TC (1990) Histochemical analysis of CaMV ${ }^{35} \mathrm{~S}$ promoter- $\beta$-glucuronidase gene expression in transgenic rice plants. Plant Mol Biol 15, 527-538

Becker D, Brettschneider R, Lörz H (1994) Fertile transgenic wheat from microprojectile bombardment of scutellar tissue. Plant $J 5,299-307$

Bevan MW, Flavell RB, Chilton MD (1983) A chimaeric antibiotic resistance gene as a selectable marker for plant cell transformation. Nature (Lond) 394, 184187

Bower R, Birch RG (1992) Transgenic sugarcane plants via microprojectile bombardment. Plant $\mathrm{J} 2$, 409-416

Callis J, Fromm M, Walbot V (1987) Introns enhance gene expression in cultured maize cells. Gene Dev $1,1183-1200$

Campbell WH, Gowri G (1990) Codon usage in higher plants, green algae, and cyanobacteria. Plant Physiol 92, 1-11

Casas AM, Knonowicz AK, Zehr UB et al (1993) Transgenic sorghum plants via microprojectile bombardment. Proc Natl Acad Sci USA 90, 1121211216

Castillo AM, Vasil V, Vasil IK (1994) Rapid production of fertile transgenic plants of rye (Secale cereale $L$ ). Biotechnology 12, 1366-1371

Chalfie M, Tu Y, Euskirchen G, Ward WW, Prasher DC (1994) Green fluorescent protein as a marker for gene expression. Science 263, 802-805

Chan MT, Chang HH, Ho SL, Tong WF, Yu SM (1993) Agrobacterium-mediated production of transgenic rice plants expressing a chimeric $\alpha$-amylase promoter//-glucuronidase gene. Plant Mol Biol 22, 491506

Chibbar RN, Kartha KK, Datla RSS, Leung N, Caswell K, Mallard CS (1993) The effect of different promotersequences on transient expression of gus reporter gene in cultured barley (Hordeum vulgare $L$ ) cells. Plant Cell Rep 12, 506-509

Christensen AH, Sharrock RA, Quail RH (1992) Maize polyubiquitin genes: structure, thermal perturbation of expression and transcript splicing, and promoter activity following transfer to protoplasts by electroporation. Plant Mol Biol 18, 675-689

Christou $P$ (1993) Particle gun mediated transformation. Curr Op Biotech 4, 135-141

Christou P, Ford TL, Kofron M (1991) Production of transgenic rice (Oryza sativa $L$ ) plants from agronomically important indica and japonica varieties via electric discharge particle acceleration of exogenous DNA into mature zygotic embryos. Biotechnology 9, 957-962 
Cooley J, Ford T, Christou P (1995) Molecular and genetic characterization of elite transgenic rice plants produced by electric-discharge particle acceleration. Theor App/ Genet 90, 97-104

Cornejo MJ, Luth D, Blankenship KM, Anderson OD, Blechl AE (1993) Activity of a maize ubiquitin promoter in transgenic rice. Plant $\mathrm{Mol}$ Biol 23, 567581

D'Halluin K, Bonne E, Bossut M, de Beuckeleer M, Leemans J (1992) Transgenic maize plants by tissue electroporation. Plant Cell 4, 1495-1505

Datta SK, Peterhans A, Datta K, Potrykus I (1990) Genetically engineered fertile indicarice recovered from protoplasts. Biotechnology 8, 736-740

Eichholtz DA, Rogers SG, Horsch RB et al (1987) Expression of a mouse dihydrofolate reductase gene confers methotrexate resistance in transgenic petunia plants. Som Cell Mol Genet 13, 67-76

Finer JF, Vain P, Jones MW, McMullen MD (1992) Development of the particle inflow gun for DNA delivery to plant cells. Plant Cell Rep 11, 323-328

Frame BR, Drayton PR, Bagnal SV et al (1994) Production of fertile transgenic maize plants by silicon carbide whisker-mediated transformation. Plant J 6, 941-948

Fromm ME, Morrish F, Armstrong C, Williams R, Thomas J, Klein TM (1990) Inheritance and expression of chimeric genes in the progeny of transgenic maize plants. Biotechnology 8, 833-839

Fujimoto $\mathrm{H}$, Itoh $\mathrm{K}$, Yamamoto $\mathrm{M}$, Kyozuka J, Shimamoto K (1993) Insect-resistant rice generated by introduction of a modified $\delta$-endotoxin gene of Bacillus thuringiensis. Biotechnology 11, 1151-1155

Goodall GJ, Filipowicz W (1989) The AU-rich sequences in the introns of plant nuclear premRNAs are required for splicing. Cel/ 58, 473-483

Gordon-Kamm WJ, Spencer M, Mangano ML et al (1990) Transformation of maize cells and regeneration of fertile transgenic plants. Plant Cell 2, 603618

Goto F, Toki S, Uchimiya H (1993) Inheritance of a cotransferred gene in the progenies of transgenic rice plants. Transgen Res 2, 300-305

Gotor C, Romero LC, Inouye K, Lam E (1993) Analysis of three tissue-specific elements from the wheat Cab-1 enhancer. Plant J 3, 509-518

Grimsley N, Hohn T, Davies JW, Hohn B (1987) Agrobacterium mediated delivery of infectious maize streak virus into maize plants. Nature (Lond) 325, 177-179

Gritz L, Davies J (1983) Plasmid-encoded hygromycin $B$ resistance: the sequence of hygromycin B phosphotransferase and its expression in Escherichia coli and Saccharomyces cerevisiae. Gene 25, 179188

Hartman CL, Lee L, Day PR, Tumer NE (1994) Herbicide resistant turfgrass (Agrostis palutris Huds) by biolistic transformation. Biotechnology 12 , 919-923
He DG, Mouradov A, Yang YM, Mouradova E, Scott KJ (1994) Transformation of wheat (Triticum aestivum L) through electroporation of protoplasts. Plant Cell Rep 14, 192-196

Hiei Y, Ohta S; Komari T, Kumashiro (1994) Efficient transformation of rice (Oryza sativa $L$ ) mediated by Agrobacterium and sequence analysis of the boundaries of the T-DNA. Plant $J 6,271-282$

Hunold R, Bronner R, Hahne G (1994) Early events in microprojectile bombardment: cell viability and particle location. Plant J 5, 593-604

Ingelbrecht ILW, Herman LMF, Dekeyser RA, vanMontagu MC, Depicker AG (1989) Different $3^{\prime}$ end regions strongly influence the level of gene expression in plant cells. Plant Cell 1, 671-680

Jähne A, Becker D, Brettschneider R, Lörz H (1994) Regeneration of transgenic, microspore-derived, fertile barley. Theor App/ Genet 89, 525-533

Kaeppler HF, Somers DA, Rines HW, Cockburn AF (1992) Silicon carbide fiber-mediated stable transformation of plant cells. Theor Appl Genet 84, 560566

Kikkert JR (1993) The Biolistic ${ }^{\circledR}$ PDS-1000/He device. Plant Cell, Tissue Organ Cult 33, 221-226

Klöti A, Iglesias VA, Wünn J, Burkhardt PK, Datta SK, Potrykus I (1993) Gene transfer by electroporation into intact scutellum cells of wheat embryos. Plant Cell Rep 12, 671-675

Koziel MG, Beland GL, Bowman CB et al (1993) Field performance of elite transgenic maize plants expressing an insecticidal protein derived from Bacillus thuringiensis. Biotechnology 11, 194-195

Kyozuka J, Fujimoto H, Izawa T, Shimamoto K (1991) Anaerobic induction and tissue-specific expression of maize Adh1 promoter in transgenic rice plants and their progeny. Mol Gen Genet 228, 40-48

Kyozuka J, Hayashi Y, Shimamoto K (1990) Effect of the promoter and the first intron of maize Adh1 on foreign gene expression in rice. Maydica 35, 353357

Kyozuka J, McElroy D, Hayakawa T, Xie Y, Wu R, Shimamoto K (1993) Light-regulated and cell-specific expression of tomato rbcs-gusA and rice rbcsgusA fusion genes in transgenic rice. Plant Physiol 102, 991-1000

Last DI, Brettell RIS, Chamberlain DA et al (1991) pEmu: an improved promoter for gene expression in cereal cells. Theor Appl Genet 81, 581-588

Li L, Qu R, de Kochko A, Fauquet C, Beachy RN (1993) An improved rice transformation system using the biolistic method. Plant Cell Rep 12, 250255

Lowe K, Bowen G, Hoerster G et al (1995) Germline transformation of maize following manipulation of chimeric shoot meristems. Biotechnology 13, 677682

Luan S, Bogorad L (1992) A rice cab gene promoter contains separate cis-acting elements that regulate expression in dicot and monocot plants. Plant Cell 4, 971-981 
Luehrsen KR, Walbot V (1991) Intron enhancement of gene expression and the splicing efficiency of introns in maize cells. Mol Gen Genet 225, 81-93

Luo Z, Wu R (1988) A simple method for the transformation of rice via the pollen-tube pathway. Plant Mol Biol Rep 6, 165-174

Lusardi MC, Neuhaus-Url G, Potrykus I, Neuhaus G (1994) An approach towards genetically engineered cell fate mapping in maize using the Lc gene as a visible marker; transactivation capacity of Lc vectors in differentiated maize cells and microinjection of LC vectors into somatic embryos and shoot apical meristems. Plant J 5, 571-582

Lynch PT, Benson EE, Jones J, Cocking EC, Power JD, Davey MR (1994) Rice cell cryopreservation: the influence of culture methods and the embryogenic potential of cell suspensions on post-thaw recovery. Plant Sci 98, 185-192

Maas C, Laufs J, Grant S, Korfhage C, Werr W (1991) The combination of a novel stimulatory element in the first exon of the maize shrunken-1 gene with the following intron 1 enhances reporter gene expression up to 1 000-fold. Plant Mol Biol 16, 199-207

Maheshwari N, Rajyalakshmi K, Baweja K, Dhir SK, Chowdhry CN, Maheshwari SC (1995) In vitro culture of wheat and genetic transformation. Retrospect and prospect. Crit Rev Plant Sci 14, 149-178

McElroy D, Wanggen Z, Cao J, Wu R (1990) Isolation of an efficient actin promoter for use in rice transformation. Plant Cell 2, 163-171

McElroy D, Blowers AD, Jenes B, Wu R (1991) Construction of expression vectors based on the rice actin 1 (Act1) 5 region for use in monocot transformation. Mol Gen Genet 231, 150-160

McElroy D, Brettell RIS (1994) Foreign gene expression in transgenic cereals. Tib Tech 12, 62-68

McElroy D, Chamberlain DA, Moon E, Wilson KJ (1995) Development of gusA reporter gene constructs for cereal transformation: availability of plant transformation vectors from the CAMBIA Molecular Genetic Resource Service. Mol Breed 1, 27-37

Medberry SL, Olszewski NE (1993) Identification of cis elements involved in Commelina yellow mottle virus promoter activity. Plant J 3, 619-626

Meijer EGM, Schilperoort RA, Rueb S, van OsRyugrok PE, Hensgens LAM (1991) Transgenic rice cell lines and plants: expression of transferred chimeric genes. Plant Mol Biol 16, 807-820

Montain Laursen C, Krzyzek RA, Flick CE, Anderson PC, Spencer TM (1994) Production of fertile transgenic maize by electroporation of suspension culture cells. Plant Mol Biol 24, 51-61

Murakami T, Anzai H, Imai S, Satoh A, Nagaoka D, Thompson CJ (1986) The bialaphos biosynthetic genes of Streptomyces hygroscopicus: molecular cloning and characterization of the gene cluster. Mol Gen Genet 221, 245-250

Murray EE, Lotzer J, Eberle M (1989) Codon usage in plant genes. Nucleic Acids Res 17, 477-493
Murry LE, Elliot LG, Capitant SA et al (1993) Transgenic corn plants expressing MDMV strain B coat protein are resistant to mixed infections of maize dwarf mosaic virus and maize chlorotic mottle virus. Biotechnology 11, 1559-1564

Nehra NS, Chibbar RN, Leung et al (1994) Self-fertile transgenic wheat plants regenerated from isolated scutellar tissues following microprojectile bombardment with 2 distinct gene constructs. Plant J 5, 285297

Oard JH, Paige D, Dvorak J (1989) Chimeric gene expression using maize intron in cultured cells of breadwheat. Plant Cell Rep 8, 156-160

Olive MR, Walker JC, Singh K, Dennis ES, Peacock WJ (1990) Functional properties of the anaerobic responsive element of the maize Adh1 gene. Plant Mol Biol 15, 593-604

Omirulleh S, Abraham M, Golovkin M et al (1993) Activity of a chimeric promoter with the doubled CaMV ${ }^{35} \mathrm{~S}$ enhancer element in protoplast derived cells and transgenic plants in maize. Plant Mol Biol 21, 415-428

Pattishall KH, Acar J, Burchall JJ, Goldstein FW, Harvey RJ (1977) Two distinct types of trimethoprim-resistant dihydrofolate reductase specified by R-plasmids of different compatibility groups. $J$ Biol Chem 252, 2319-2323

Peng J, Lyznik A, Lee L, Hodges TK (1990) Cotransformation of indica rice protoplasts with GUS and Neo genes. Plant Cell Rep 9, 168-172

Perlak FJ, Fuchs RL, Dean DA, McPherson SL, Fischhoff DA (1991) Modification of the coding sequence enhances plant expression of insect control protein genes. Proc Natl Acad Sci USA 88, 3324-3328

Peterhans A, Datta SK, Datta K, Goodall GJ, Potrykus I, Paszkowski J (1990) Recognition efficiency of Dicotyledoneae-specific promoter and RNA processing signals in rice. Mol Gen Genet 222, 361368

Potrykus I (1990) Gene transfer to cereals: an assessment. Biotechnology 8, 532-542

Rathore KS, Chowdhury VK, Hodges TK (1993) Use of bar as a selectable marker gene and for the production of herbicide-resistant rice plants from protoplasts. Plant Mol Biol 21, 871-884

Rathus C, Bower R, Birch RG (1993) Effects of promoter, intron and enhancer elements on transient gene expression in sugar-cane and carrot protoplasts. Plant Mol Biol 23, 613-618

Register JC III, Peterson DJ, Bell PJ et al (1994) Structure and function of selectable and non-selectable transgenes in maize after introduction by particle bombardment. Plant Mol Biol 25, 951-961

Ritala A, Aspergren K, Kurten $U$ et al (1994) Fertile transgenic barley by particle bombardment of immature embryos. Plant Mol Biol 24, 317-325

Rhodes CA, Pierce DA, Mettler IJ, Mascarenhas D, Detmer JJ (1988) Genetically transformed maize plants from protoplasts. Science 240, 204-206 
Schäffner AR, Sheen J (1991) Maize rbcs promoter activity depends on sequence elements not found in dicot rbcs promoters. Plant Cell 3, 997-1012

Shimamoto K, Terada R, Izawa T, Fujimoto H (1989) Fertile transgenic rice plants from transformed protoplasts. Nature (Lond) 338, 274-276

Simmonds J, Steward P, Simmonds D (1992) Regeneration of Triticum aestivum apical explants after microinjection of germ line progenitor cells. Physiol Plantarum 85, 197-206

Somers DA, Rines HW, Gu W, Kaeppler HF, Bushnell WR (1992) Fertile, transgenic oat plants. Biotechnology 10, 1589-1594

Songstad DD, Halaka FG, DeBoer DL et al (1993) Transient expression of GUS and anthocyanin constructs in intact maize immature embryos following electroporation. Plant Cell Tissue Organ Cult 33, 195-201

Spangenberg G, Wang ZY, Nagel J, Potrykus I (1994) Protoplast culture and generation of transgenic plants in red fescue (Festuca rubra L). Plant Sci 97 , 83-94

Spangenberg G, Wang ZY, Wu XL, Nagel J, Iglesias VA, Potrykus I (1995a) Transgenic tall fescue (Festuca arundinacea) and red fescue ( $F$ rubra) plants from microprojectile bombardment of embryogenic suspension cells. J Plant Physiol 145, 693-701

Spangenberg G, Wang ZY, Wu XL, Nagel J, Potrykus I (1995b) Transgenic perennial ryegrass (Lolium perenne) plants from microprojectile bombardment of embryogenic suspension cells. Plant Sci 108, 209-217

Spencer TM, O'Brien JV, Start WG, Adams TR, Gordon-Kamm WJ, Lemaux PG (1992) Segregation of transgenes in maize. Plant Mol Biol 18, 201-210

Tanaka A, Satoru M, Ohta S, Kyozuka J, Shimamoto $K$ (1990) Enhancement of foreign gene expression by a dicot intron in rice but not in tobacco is correlated with an increased level of mRNA and an efficient splicing of the intron. Nucl Acids Res 18, 6767-6770

Terada R, Shimamoto K (1990) Expression of CaMV 35 S-GUS gene in transgenic rice plants. Mol Gen Genet 220, 389-392

Terada R, Nakayama T, Iwabuchi M, Shimamoto $K$ (1995) A type I element composed of the hexamer (ACGTCA) and octamer (CGCGGATC) motifs plays a role(s) in meristematic expression of a wheat histone $\mathrm{H} 3$ gene in transgenic rice plants. Plant $\mathrm{Mol}$ Biol 27, 17-26

Toki S, Takamatsu S, Nojiri C et al (1992) Expression of a maize ubiquitin promoter-bar chimeric gene in transgenic rice plants. Plant Physiol 100, 1503 1507

Vain P, McMullen MD, Finer J (1993) Osmotic treatment enhances particle bombardment-mediated transient and stable transformation of maize. Plant Cell Rep 12, 84-88
Vasil V, Clancy M, Ferl RJ, Vasil IK, Hannah LC (1989) Increased gene expression by the first intron of maize shrunken-1 locus in grass species. Plant Physiol 91, 1575-1579

Vasil V, Castillo AM, Fromm ME, Vasil IK (1992) Herbicide-resistant fertile transgenic wheat plants obtained by microprojectile bombardment of regenerable embryogenic callus. Biotechnology 10, 667674

Vasil V, Srivastava V, Castillo AM, Fromm ME, Vasil IK (1993) Rapid production of transgenic wheat plants by direct bombardment of cultured immature embryos. Biotechnology 11, 1553-1558

Walters DA, Vetsch CS, Potts DE, Lundquist RC (1992) Transformation and inheritance of a hygromycin phosphotransferase gene in maize plants. Plant Mol Biol 18, 189-200

Wan Y, Lemaux PG (1994) Generation of large numbers of independently transformed fertile barley plants. Plant Physiol 104, 37-48

Wang ZY, Takamizo T, Iglesias VA et al (1992) Transgenic plants of tall fescue (Festuca arundinacea Schreb) obtained by direct gene transfer to protoplasts. Biotechnology 10, 691-696

Wang ZY, Legris G, Nagel J, Potrykus I, Spangenberg $G$ (1994) Cryopreservation of embryogenic cell suspensions in Festuca and Lolium species. Plant Sci 103, 93-106

Weeks JT, Anderson OD, Blechl AE (1993) Rapid production of multiple independent lines of fertile transgenic wheat (Triticum aestivum). Plant Physiol 102, 1077-1084

Wohlleben W, Arnold W, Broer I, Hillemann D, Strauch $E$, Pühler A (1988) Nucleotide sequence of the phosphinothricin $\mathrm{N}$-acetyltransferase gene from Streptomyces viridochromogenes Tü494 and its expression in Nicotiana tabacum. Gene 70, 25-37

Xu D, McElroy D, Thornburg RW, Wu R (1993) Systemic induction of a potato pin2 promoter by wounding, methyl jasmonate, and abscisic acid in transgenic rice plants. Plant $\mathrm{Mol} \mathrm{Biol} 22,573-588$

Xu X, Li B (1994) Fertile transgenic indica rice plants obtained by electroporation of the seed embryo cells. Plant Cell Rep 13, 237-242

Yin $Y$, Beachy RN (1995) The regulatory regions of the rice tungro bacilliform virus promoter and interacting nuclear factors in rice (Oryza sativa L). Plant $J 7$, 969-980

Zhang W, McElroy D, Wu R (1991) Analysis of rice act 15 region activity in transgenic rice plants. Plant Cell 3, 1155-1165

Zheng Z, Kawagoe Y, Xiao S et al (1993) 5' Distal and proximal cis-acting regulator elements are required for developmental control of a rice seed storage protein glutelin gene. Plant $J$ 4, 357-366

Zhong $\mathrm{H}$, Bolyard MG, Srinivasan $\mathrm{C}$, Stickelen M (1993) Transgenic plants of turfgrass (Agrostis palutris Huds) from microprojectile bombardment of embryogenic callus. Plant Cell Rep 13, 1-6 